\author{
Anna Horodecka \\ Warsaw School of Economics, Collegium of Economic Analysis \\ e-mail: ahorod@sgh.waw.pl
}

\title{
The Changing Face of Economics? Ethical Issues in Contemporary Economic Schools as a Consequence of Changes in the Concept of Human Nature*
}

\begin{abstract}
The last financial crisis combined with some recent social trends (like growing inequality or environmental problems) inspired many contemporary economists to the re-evaluation of actual economic knowledge in the search for solutions to these problems. Modern economic schools (especially heterodox ones) stress the meaning of ethical issues in economics more often. The thesis of the paper is that this revival of the ethical face of present economics depends very strongly on the changing assumptions of human nature within economics and other disciplines which work alongside economics, such as social psychology or business ethics, for instance. In order to prove the thesis, the paper provides an evaluation of current economic schools, especially within the heterodoxy, in search of their ethical aspects, and presents them as a result of the changing assumptions about human beings within those schools. This ethical dimension of human beings manifests itself in different ways, which can be perceived as a result of it being based on different ethical schools and different psychological and philosophical assumptions about human nature. Therefore, the paper also considers the current developments of the view on human beings in contemporary schools of economic ethics.
\end{abstract}

Keywords: business ethics, heterodox economic schools, economic anthropology; concept of human nature

JEL Classification: B25, B50, B52, B54, B59, Q57, Z13

\footnotetext{
* The research was financed by the National Science Centre Poland (UMO-2011/03/D/HS4/00849).
} 


\section{Introduction}

During the last few decades our economy and society have encountered various economic and social crises and problems, which have provoked lively debates by economists. Contemporary economists feel prompted by the situation to re-evaluate contemporary economic knowledge in order to find solutions to the current problems. Heterodox economists tend to blame orthodox economics for having failed to provide explanations and answers to present problems. The reason for the failure is seen in the concept of human nature, which provides the foundations upon which mainstream economics are built. However, this concept is criticized for various reasons, which are discussed elsewhere. ${ }^{1}$ This paper focuses mainly on the ethical aspects, which are missing in the neoclassical concept. It is possible to regain the ethical face of economics if the economists acknowledge that the ethical dimension of human beings exists. ${ }^{2}$ The first platform to discover the ethical nature of the human being can be found in the diverse modern approaches to economic ethics, which combine two views of the economic actor - the economic and the ethical. Some of those approaches are further developed by economists (like the 'Capability approach' of Amartya Sen, 'integrative ethics' by Peter Ulrich, 'Governance ethics' by Josef Wieland, or 'economic ethics' by Karl Homan), and others by philosophers (ethicians) - like discourse ethics by Jürgen Habermas, or communitarianism, by Amitai Etzioni. This has diverse consequences on how economics is perceived, sometimes giving supremacy to ethics, sometimes to economics, while at other times it looks to combine both. ${ }^{3}$ The other platform where we can observe the rebirth of the ethical face of economics is in heterodox economics. Diverse schools in heterodox economics incorporate ethical aspects into their understanding of human beings, and therefore economics. Ethical reasoning also takes various forms -

\footnotetext{
1 A. Horodecka, Homo oeconomicus, jako podstawa ekonomii - krytyka i alternatywy [Homo economicus, as the basis of economics - criticism and alternatives], "Prace Naukowe Uniwersytetu Ekonomicznego we Wrocławiu" 2014, No. 347, pp. 166-183.

${ }^{2}$ Within management studies, ethical aspects of human nature found their way before, discussed: A. Horodecka, The meaning of concepts of human nature in organizational life in business ethical context, "Annales. Etyka w życiu gospodarczym / Annales. Ethics in Economic Life" 2014, Vol. 17, No. 4, pp. 53-64; A. Horodecka, E. Mazur-Wierzbicka, The meaning of the concept of human nature in the organization and ethical concepts supporting CSR [in:] CSR - Spoleczny wymiar działalności biznesowej, ed. E. Mazur-Wierzbicka, Economicus, Szczecin 2014; A. Horodecka, Rola obrazów człowieka $w$ koncepcjach zarządzania $z$ uwzględnieniem aspektów metodologicznych [The role of human images in the concepts of management, taking into account methodological aspects], [in:] Studia Ekonomiczne Nauki o zarządzaniu - u początków $i$ współcześnie, ed. A. Czech, Uniwersytet Ekonomiczny w Katowicach, Katowice 2012, pp. 443-464.

${ }^{3}$ There are some research programs in economic and business ethics which assume the superiority of ethical judgment over the results of economics analysis: A. Etzioni, Toward a Kantian Socio-Economics, "Review of Social Economy" 1987, Vol. 45, No. 1; N.E. Bowie, A Kantian Theory of Meaningful Work, "Journal of Business Ethics" 1998, Vol. 17, pp. 1083-1092; P. Ulrich, Integrative Economic Ethics: Foundations of a Civilized Market Economy, Cambridge University Press, Cambridge 2008, see: J. Wieland, Governance ethics: Global value creation, economic organization and normatively, Springer, 2014, p. 4.
} 
tending more towards utilitarianism, common for neoclassical economic thinking, or towards some more deontological approaches going beyond individual or even beyond utilitarian reasoning.

Therefore, in the first section, the paper reviews contemporary ethical schools which deal with economic problems, and count to economic ethics approaches, focusing on the effects of their understanding of human nature on the understanding of the challenges of economics? In the second section, current trends in economic heterodox schools are discussed, referring to their concept of human nature. Does it have some ethical aspects and how they are reflected by economics? What are those ethical aspects? What kind of ethical reasoning is used there?

\section{The changing face of economics: current developments in mod- ern approaches to economic ethics}

Modern economic ethics schools started to develop in the 1980s as philosophers, politicians, sociologist and society in general started to highlight the limits of pure economic thinking in solving the contemporary problems. Those problems are primarily concerned with ecology (the emergence of the Club of Rome marked a significant point on the timeline), but also with growing inequality, starvation, corruption, economic and financial crises and health. The issues discussed by the expansive nature of economic thinking was extremely broad, covering even private spheres of living like marriage, the family or religion. ${ }^{4}$ During last decades the trend started to reverse and the ethical reasoning came back to the economics. 'Coming back' refers to the fact, that originally ethics was a fundamental part of the economics (like for Aristotle or Adam Smith).

Economic ethics (developed by Karl Homan ${ }^{5}$ ) was one of first responses to the lack of ethical frames for economics. However, it hasn't adapted ethical concept of human nature, sticking to the egoistic, utility-maximizing model of man. But such behavior can have negative effects on other people or on nature (these negative effects are called due to Arthur Pigou 'external effects') and diminish the utility of these other persons. Basing on the idea of utilitarianism developed by Jeremy Bentham, John Stuart Mill, ${ }^{6}$ Karl Homan considers such behavior as unethical. Therefore, the maximizing behavior has to be woven into the network of state regulations, so that the choice of moral good for the individual remains profitable (for instance: through taxes, regulations, controls). The ethical face of economics is therefore reduced only to the regulative framework put on the market. In other words - economics requires political embedding, which it ethical once again.

\footnotetext{
${ }^{4}$ See: G.S. Becker, The economic approach to human behavior [in:] The Economics Approach to Human Behavior, ed. G.S. Becker, University of Chicago Press, Chicago 1976, pp. 3-14.

${ }^{5}$ K. Homann, F. Blome-Drees, Wirtschafts- und Unternehmensethik, Vandenhoeck \& Ruprecht, Göttingen 1992.

${ }^{6}$ J. Bentham, J. S. Mill, The utilitarians, Anchor Press, Garden City, NY 1973.
} 
Governance ethics (developed by Josef Wieland ${ }^{7}$ ) focuses primarily on the moral dimension $(\mathrm{Tm})$ of individual business transactions. This is a function of individual self-control mechanisms (IS) with their background in the principles of virtue and other mechanisms, ${ }^{8}$ both formal $(F I)$ and informal institutions $(I F)$ of the institutional environment (which as well has moral components) and the nature of coordination and cooperation mechanisms of the economic organization (OCC) depending on a specific transaction $(i)$, and specific place $(j)$ :

$$
\operatorname{Tm}_{i}=f\left(a I S_{i}, b F I_{i j}, c I F_{i j}, d O C C_{i}\right) .
$$

Attention is also drawn here to the fact that, in order to reduce the high transaction costs discussed in agency theory (the principal-agent problem ${ }^{9}$ ), managers should strive for some 'governance' rules, and the ethical education of the workforce. An excellent tool is a well-designed and properly supervised 'code of ethics', emphasizing, among others, the need for the formation of human character as well as values management. ${ }^{10}$ The code is also an agreement regarding the creation of an immanent model of man within the organization - the model of an ideal employee. Morality is here treated as an individual and a collective resource that must be activated by a special management system, i.e. individual commitments, supervision of formal and informal institutions or a mechanism for cooperation and coordination in the organization. The rules of 'governance', useful for activation, can be divided according to two criteria: formal/informal and private/public. ${ }^{11}$ The human being is considered to be motivated by his social surroundings and therefore some ethical conformism (a conventional stage in the development of a person) may be a good starting point for further moral education. Because the standards and values of the organization should be common and should meet the needs of the community, the process of their assimilation takes place within the organization. The relationship to nature and ecological aspects might not be discussed separately, depending on the values of the particular community. ${ }^{12}$ Summing up, Governance Ethics widens the scope of ethical discourse (for instance the responsibility of actions) not limiting it only to the state level, but distinguishing many levels of responsibility: individual, that of the organization (coordination, cooperation mechanisms), of society and its culture (informal), and of the state and global society. ${ }^{13}$ The union of all those levels contributes to the moral dimension of economic transactions. The individual is coresponsible for his/her action and, in a further sense, is the co-creator of the culture.

\footnotetext{
${ }^{7}$ Developed by J. Wieland, Die Ethik der Governance, Metropolis-Verl., Marburg 2004.

${ }^{8} \mathrm{~J}$. Wieland, Corporate governance, values management, and standards: an European perspective, "Business \& Society" 2005, Vol. 44, No. 1, pp. 74-93 (esp. p. 74); Idem, Governance ethics: Global value creation, economic organization and normatively, op. cit., p. 16.

${ }^{9}$ K. Eisenhardt, Agency theory: An assessment and review, “Academy of Management Review” 1989, Vol. 14, No. 1, pp. 57-74.

${ }^{10}$ D. Collins, Essentials of business ethics: Creating an organization of high integrity and superior performance, John Wiley \& Sons, 2009.

${ }_{11}^{11}$ M. Karmasin, M. Litschka, Wirtschaftsethik: Theorien, Strategien, Trends, Lit-Verl., Wien 2008.

12 J. Wieland, Die Ethik...; Idem, Eine Theorie der Governanceethik, "Zeitschrift für Wirtschafts-und Unternehmensethik" 2001, Vol. 2, No. 1, pp. 8-33.

${ }^{13}$ Wieland stresses here as well the necessity of effective global rules for economic transactions. He maintains that the law, its enforcement and moral standards of behavior constitute basic requirements for efficient economic activities. Idem, Governance ethics..., p. 61.
} 
Integrative ethics (developed by Peter Ulrich and his St. Gallen Institute) maintains that the moral character of the individual and his social actions are based both on economic logic and ethical substantive reasoning, which should be shaped in a new way - oriented for the future and serving life (German: Lebensdienlichkeit). ${ }^{14}$ The life-serving principle is considered superior to the logic of the market, which used alone is inconsistent, lacks an ethical sense and cannot cope with the contemporary problems of the economy, which cannot be limited only to the issue of efficiency. These problems include diverse social conflicts (both values and interests) for the division of internal and external costs and benefits of the process of rationalization. ${ }^{15}$ Therefore, the conflict between economic rationality and ethical reasoning should be resolved through so called socio-economic rationality, which includes ethical point of view. ${ }^{16}$ At the individual level, it is assumed that a person is able to subordinate his activities and behavior to the norms and values of the group, whereby the guiding principle is the recognition of others as units with the same dignity. ${ }^{17}$ Morality is therefore understood as a freedom under the recognition of inter-subjectivity, ${ }^{18}$ which is rooted in the social structure, based on the acknowledging of the symmetry of interpersonal relationships ('interhumanity' translated from the German original: Zwischenmenschlichkeit ${ }^{19}$ ). Individual motives are therefore subordinated to the principle of the convertibility of inter-subjective perspectives. The social level of the concept of human nature is based on the principle of the total equality of people (which translates into the principle of symmetry) and their mutual dependence. The relationship to nature is marked by the attitude of responsible economic actions which respect the future generations.

Communitarianism (developed by Amitai Etzioni) ${ }^{20}$ is based on the idea that values and norms are dependent on the culture. It is critical of the idea of the absolute freedom of the individual choosing values without regarding their social value. Communitarianism gives priority to social and political communities and requires that moral values should take into account the interests of the community. The individual's development has to be compatible with the accordance of the values of the society, which can be quickened by means of education, business leadership, consensus, the pressure of groups and social role models. The value of the community in which the person is located is given a greater priority over the choice of the individual. At the social level, the concept of human nature is based on the idea of the dependence and subordination of the individual to society, which allows for self-realization. Individual success is per-

\footnotetext{
${ }^{14}$ See: P. Ulrich, Integrative Wirtschaftsethik: Grundlagen einer lebensdienlichen Ökonomie, Haupt, Bern 2001, p. 20.

${ }^{15}$ See: Idem, Integrative Wirtschaftsethik: Grundlagenreflexion der ökonomischen Vernunft, "Ethik und Sozialwissenschaften" 2000, Vol. 11, No. 4, pp. 555-567.

${ }^{16}$ Idem, Integrative Wirtschaftsethik: Grundlagen einer lebensdienlichen Ökonomie, op. cit., p. 17.

${ }^{17}$ O. Höffe, Humanität [in:] Lexikon der Ethik, ed. O. Höffe, München 1980, pp. 112-113 (esp. p. 113).

${ }^{18}$ A. Pieper, Einführung in die Ethik [in:] Mut zum Aufbruch. Eine wirtschaftspolitische Agenda für die Schweiz, ed. D. Hauser, H.B. Schmid, Zürich 1995, p. 43.

${ }^{19} \mathrm{P}$. Ulrich, Integrative Wirtschaftsethik-eine Heuristik auch für die Technikethik? [in:] Technikethik und Wirtschaftsethik, Springer, 1998, pp. 53-74 (esp. p. 23ff).

${ }^{20}$ A. Etzioni, The Essential Communitarian Reader, Rowman \& Littlefield, Lanham 1998; Idem, Moral Dimension: Toward a New Economics, Simon and Schuster, 2010.
} 
ceived not only as a result of individual effort, but of the whole community, and therefore the individual is obliged to 'reciprocity', i.e. paying tribute to the community. The relationship to nature depends on the values and norms of that community.

The 'capability approach' developed by Amartya Sen, ${ }^{21}$ and later by Martha Nussbaum, ${ }^{22}$ focuses on the interpersonal differences between people and their diverse possibilities (capabilities) to meet their needs. ${ }^{23}$ However it assumes that all persons, regardless of those differences, have the right to wellbeing. It focuses on solving the most important global problems, like social inequality and poverty. The capability approach introduces a very important differentiation between 'functionings', referring to all desirable 'doings' and 'beings', and 'capabilities'. Acquiring wellbeing depends on so-called 'converting factors', which transform our resources into factual functionings. These converting factors can be divided into individual (health, gender), social (social constraints and facilities) and environmental (physical environment, climate). Whereas standard economics focuses on resources and their distribution, the capability approach maintains that, due to diverse conversion factors, we need different amounts of resources to meet our needs and so we need to focus on ends - functionings and capabilities. Income (a resource) is only one of the ways to acquire wellbeing, but it is not the only one - we also have to integrate into our analysis 'converting factors'. Such thinking is a result of the concept of human nature, which is based on some universal understanding of human motives: its wellbeing concept is based on some universal capabilities which ensure this wellbeing, which is the source of human motivation (not: the utility). On the social level, the approach assumes that human equality is combined with the uniqueness of each human being. The relationship to nature is derived from the idea of intergenerational justice, which is a consequence of the belief that each human being, today or tomorrow, has the same right to pursue wellbeing. However, there are some postulates to extend this approach by taking into account the intrinsic value of nature, responsibility (not only ex-post but ex-ante), and by introducing subjectivity at the collective level. ${ }^{24}$

Discourse ethics ${ }^{25}$ (developed by Karl-Otto Apel and Jürgen Habermas) is a theory which does not propose any central norm which can be adapted to solve ethical problems, but it suggests producing those norms in public (everyone can

\footnotetext{
${ }^{21}$ A. Sen, Commodities and Capabilities, North-Holland, Amsterdam 1985; Idem, Development as freedom, Univ. Press, Oxford 2001; Idem, Inequality Reexamined, Russell Sage, New York 1992.

${ }^{22}$ M.C. Nussbaum, Capabilities as fundamental entilements: Sen and Social Justice, "Feminist Economics" 2003, Vol. 9, No. 2, pp. 33-59; S. Charusheela, Social Analysis and the Capabilities Approach: A Limit to Martha Nussbaum's Universalist Ethics, "Cambridge Journal of Economics" 2009, Vol. 33, No. 6, pp. 1135-1152.

${ }_{23}^{23}$ It is a good tool, therefore, for analysing the problems of discriminated groups in society: women, the disabled, the sick. This is one of the reasons why it was adapted by feminist economics.

${ }^{24}$ J. Pelenc, M.K. Lompo, J. Ballet, J.-L. Dubois, Sustainable human development and the capability approach: Integrating environment, responsibility and collective agency, "Journal of Human Development and Capabilities" 2013, Vol. 14, No. 1, pp. 77-94.

${ }^{25}$ J. Habermas, The Theory of Communicative Action: Reason and the rationalization of society, Beacon Press, 1987; Idem, Moralbewusstsein und kommunikatives Handeln, Suhrkamp, Frankfurt am Main 2001; K.-O. Apel, Globalization and the need for universal ethics, "European Journal of Social Theory" 2000, Vol. 3, No. 2, pp. 137-155; Idem, Grenzen der Diskursethik? Versuch einer Zwischenbilanz, "Zeitschrift für philosophische Forschung" 1986, pp. 3-31; Idem, The situation of humanity as an ethical problem, "Praxis International" 1984, No. 3, pp. 250-265; Idem, Das Apriori der kommunikationsgemeinschaft, Suhrkamp, 1976.
} 
participate in it), free of violence (the position of the participant does not matter), and that there be reasonable discourse (only reasonable arguments count). A norm will be adapted which obtains the approval of the participants of the discourse. It means that the truth is to be found not somewhere in the deliberations but it is the logical result of the process of communication and the language abilities of people. ${ }^{26}$ The ability to reason and argue allows for the actualization of diverse motives, values and desires of people. These are the norms on which the individual bases his decision, and which permit him to communicate with society and find their approval or disapproval. The reason (mind) allows a person for seeing the consequences of those norms. The relationship to nature in this concept of human beings depends on the current moral, ecological and technical level of society. If the society is committed to some moral norms (like intergenerational justice for instance), and has well-functioning political institutions, appropriate technology and knowledge about possible consequences of natural resource usage and pollution for future generations, is more likely to prevent ecological catastrophes and care for the natural environment. The rules concerning the environment depend more on whether or not this problem will be noticed by the public and if everyone will be able to accept the consequences of such standards - like sustainability. A pure capitalistic society, where the capital-owner attempt to maximize the gain, hamper such a discourse. More appropriate would be a post-capitalist society, which gives to the community some control over the production and doesn't leave all the power to capital-owner who look for ways of limiting costs of the production on the costs of the society.

\section{Ethical aspects of contemporary heterodox economic schools as a result of ethical perceptions of human nature}

First of all, when speaking of ethical aspects, we have to define what we consider to be ethical aspects. Ethics generally focuses on problems which we deal with through rational reasoning, ${ }^{27}$ aiming to decide what action or solution is ' $g o o d$ ' or 'bad'. Neoclassical economics replaces this 'good-bad' criterion with 'efficient-not efficient' and calls efficient choices 'rational'. Thus, whereas economics refers to rationality only in categories of 'means', ethics focuses on the final aspects of decisions, asking whether they are 'good' or 'bad'. Ethically oriented economics would, in this sense, be based on 'wise' actions (based on principles resulting from a conviction that there is some 'good') in comparison to 'clever' ones (oriented on their utility) ${ }^{28}$ and integrating 'reasonable' actions as well (based on the calculation of the consequences of actions). Heterodox economics intends to bring back to economics this moral perspective and the question about 'good' and 'bad'. It therefore

\footnotetext{
${ }^{26}$ J. Habermas, Philosophische Anthropologie, [in:] Kultur und Kritik, ed. J. Habermas, Suhrkamp, Frankfurt 1973.

${ }^{27}$ This may include considering many alternatives, which not necessarily are profitable for the individual.

${ }^{28}$ J. Stacewicz, Etyczne przesłanki działania gospodarczego, "Problemy” 1988, No. 4, pp. 1-5.
} 
has a normative character, but it maintains that neoclassical economics is also a normative one - as long as it uses 'efficient' normatively as another way of saying 'good', and 'not efficient' is treated as 'bad'. In this sense we are always normative, even when we contradict this. A vivid example of the return of moral language in economics is the book The economics of Good and Evil (by Tomas Sedláček ${ }^{29}$ ), which became a bestseller, which is proof of the demand for such 'an ethical face of economics'. ${ }^{30}$

Ethics, by definition, refers both to the character of the person and morality. The ethical aspects in human nature comprise the virtuous character of the person - his norms and values - which goes beyond self-interest, allowing for the integrity of his behavior. Thus, speaking of the ethical aspects of current heterodox economic thought, the following questions have to be of importance (which translates into a very holistic and interdisciplinary field of economics ${ }^{31}$ ):

(1) Does economics refer in its discourse to categories of 'good' and 'bad'?

(2) Does economics refer to some general norms or values which have to be respected in order to decide if something is 'good' or 'bad' (not limited just to 'efficiency' or 'utility')

(3) Does economics refer only to the 'individual' (oriented only on self) dimension of human nature, or considers as well a 'social' dimension (referring to the relations of the individual to other people) and 'world' dimension (relating to the attitude to the nature)? ${ }^{32}$ Such issues necessarily open the perspective to common interests, values and norms, people consider the broader horizon of the consequences of individual actions

(4) Does economics, in its description of the human being, make some reference to his character, virtue, ability to choose between 'good' and 'bad' on the basis of moral reasoning, which comprises more than just the utility, ${ }^{33}$

\footnotetext{
${ }^{29}$ T. Sedláček, Ekonomia dobra i zła, Wydawnictwo EMKA, Warsaw 2012.

${ }^{30}$ On the pages of „Annales. Ethics in Economic Thought” Sedláček's ideas were analysed by J. Dzionek-Kozłowska (Ekonomia jako nauka pozytywna. Refleksje na marginesie „Ekonomii dobra i zła" Tomáša Sedláčka, "Annales. Etyka w Życiu Gospodarczym / Annales. Ethics in Economic Thought", Vol. 16, pp. 335-344; the extended English version of this article has been published as a chapter in J. Dzionek-Kozlowska, R. Matera, Ethics in Economic Thought. Selected Issues and Various Perspectives, Lodz University Press, Jagiellonian University Press, Lodz-Cracow 2015, pp. 81-89.

In Polish economic literature the same approach may be found in books by G.W. Kołodko (Wędrujący świat, Prószyński i S-ka, Warszawa 2008; Idem, Dokąd zmierza świat. Ekonomia polityczna przyszłości, Prószyński i S-ka, Warszawa 2013). These books use openly normative language restricted by neoclassical economics to speak about the contemporary economic situation.

${ }^{31}$ Holism and interdisciplinarity are necessary effect of the changes of civilization model and dynamic changes, see: A. Herman, Dokąd zmierza ekonomia?, "Kwartalnik Nauk o Przedsiębiorstwie" 2008, No. 2, pp. 4-13.

${ }^{32}$ For the basic levels of human nature compare: A. Horodecka, Komponenty obrazu czlowieka w ekonomii [Components of the concept of human nature in economics], "Kwartalnik Historii Myśli Ekonomicznej [Quarterly History of Economic Thought]” 2014, Vol. 5, No. 1, pp. 117-139. JudaisticChristian perspectives of the basic dimensions of a person: I-me, me-you, me-us. A. Rich, Wirtschaftsethik: Grundlagen in theologischer Perspektive, Gütersloher Verlagshaus, Gütersloh 1984, p. $42 \mathrm{ff}$.

${ }^{33}$ Although utilitarianism is considered to be an ethical school.
} 
(5) Does economics refer to some 'common good' ${ }^{34}$ which allows the individual to transcend his particular interests? Does this common good contain only material components, or non-material as well $?^{35}$ Social capital, ${ }^{36}$ for instance, considers such immaterial aspects of social relations which subsequently have material outcomes. ${ }^{37}$

For solving problems in the economy, we need some concepts which would help us to combine those perspectives and adjust the ethical language to economic problems and challenges. It's about developing an ethical look at economic problems, because they happen to be important not only for the individual, but they also have social and global dimensions. Without considering it, we risk encountering problems which hurt both our convictions and material interests.

Neoclassical economics doesn't allow for such ethical language, reducing human being to the 'basement' (to one individual dimension and lowest level of the concept of human nature - the 'body'-level $)^{38}$, treating him as a machine, maximizing his utility, freeing him from the bonds of society and its norms, and nature, picturing him as 'a crude caricature' when it comes to dealing with the emergent dynamics of collective phenomena. Geoffrey M. Hodgson exposes the deficiencies

\footnotetext{
${ }^{34}$ Wieland stresses the fact that the economics as meant by Adam Smith was the wealth of nations and not the wealth of shareholders.

${ }^{35}$ If the 'common good' is only a material one, there won't be other enforcing mechanisms for ethical choices as the material effect of actions. Therefore, in case of two values, one ethical like justice and one materialistic, one would choose the materialistic violating ethical once. However the effects of violated norms and values like those mentioned above, for instance, can have grave consequences (material and nonmaterial) for society, see: D. Collins, op. cit., and impede the cooperative behavior as well.

${ }^{36}$ See: N. Lin, Social Capital: A Theory of Social Structure and Action (Structural Analysis in the Social Sciences), Cambridge University Press, Cambridge, May 2002. Social capital refers to the institutions, relationships, and norms that shape the quality and quantity of a society's social interactions. Increasing evidence shows that social cohesion is critical for societies to prosper economically and for the development to be sustainable. Social capital is not just the sum of the institutions which underpin a society - it is the glue that holds them together (http://go.worldbank.org/K4LUMW43B0). There are a number of key sources of social capital (SC) in the context of social and economic development: (1) families (first building block); (2) communities (social interactions among neighbors, friends and groups, which generate social capital and the ability to work together for a common good); (3) firms (building and sustaining firms demands trust and a common sense of purpose, i.e., social capital, which reduces transactions costs); (4) civil society (SC is crucial to the non-governmental organization by providing opportunities for participation and by giving voice to those who don't have any access to formal ways of affecting change); (5) public sector (the state and its institutions is central to the functioning and welfare of any society); (6) ethinicity (ethnic relations like immigration, microenterprise development, tribal nepotism or racial conflict, show how actors sharing common values and culture can band together for mutual benefit), (7) gender (Social networks as a source of income), see: http://go.worldbank.org/XR8TFW7L20.

${ }^{37}$ If somebody keeps his word regardless if it pays off or not, and this rule is enforced by society, it makes the transactions more reliable and the probability that we will enter into them is greater, or at least the costs of 1 making such transactions are reduced (transaction costs).

38 B. Klimczak, Model człowieka gospodarujacego we wspótczesnej ekonomii [in:] Wizerunek współczesnego czlowieka gospodarującego, ed. A. Węgrzycki, Akademia Ekonomiczna w Krakowie, Cracow 2000, pp. 11-29.
} 
in 'methodological individualism' ${ }^{39}$ maintaining that: '[b]y over-emphasizing characteristics of distance, individuality, autonomy, and abstraction within economic thought, the mainstream economic practices have become severely impoverished. ${ }^{40}$

Behavioral economics is a descriptive approach, based on observation, which maintains that a person acts in different way than that assumed by neoclassical economics. This school attempts to discover rules of behavior which allow predictions of economic phenomena to be made. It is not assumed a priori what a human being is, what motives people have, what are their aims. ${ }^{41}$ The observation delivers results which contradict the utilitarian, egoistic, rational nature of human beings, showing emotional elements. ${ }^{42}$ Does behavioral economics make any space for ethical consideration? Yes, in the sense that, through such observations and experiments, it comes to the conclusion that there are some unwritten rules of cooperation and social interchange, which contradict the idea of maximizing behavior. It finds empirical evidence for some tendencies in behavior which we would describe with ethical language as oriented towards some norms and values. So the observed reciprocity ${ }^{43}$ indicates the belief in fairness, and the emphasis on behavior oriented towards satisfaction and not optimization speaks for the superiority of needs over preferences.

Feminist economics ${ }^{44}$ deals with a range of phenomena. The kind of phenomenon depends on the principle of whether it has to do with some practical problems of society and not abstract ones like in neoclassical economics. Therefore, what counts most are the real needs of society, the cultural context, and gender problems. The analyzed phenomena are considered by assuming that justice, equal rights and real needs matter. Taking a closer look at the gendered speech and attitudes to the science, feminist economics criticized the fact that many solutions to given problems are based on power relations (discussed earlier by critical theory ${ }^{45}$ ). This is a consequence of the assumed concept of human nature which, at the individual level, considers the socially made differences

\footnotetext{
${ }^{39}$ Peter Corning (Institute for the Study of Complex Systems and the author of The Fair Society) about: G.M. Hodgson, From Pleasure Machines to Moral Communities, An Evolutionary Economics without Homo economicus, University of Chicago Press, Chicago 2012.

For the main critical arguments contra homo oeconomicus compare as well: A. Horodecka, Homo oeconomicus, jako podstawa ekonomii - krytyka i alternatywy [Homo economicus, as the basis of economics - criticism and alternatives], op. cit., pp. 166-183.

${ }^{40}$ J.A. Nelson, Economists, value judgments, and climate change: A view from feminist economics, "Ecological economics" 2008, Vol. 65, No. 3, pp. 441-447.

${ }^{41}$ Such a formulation underlies the assumption that our observation delivers objective results, and that it diminishes the fact that language makes our world, according to Wittgenstein. It means, for once, that when we do not look for norms and values, they cannot be revealed by themselves. We still make some assumptions about the world we perceive. Behavioral economics reduces such assumptions to those which are used in the objective sciences, like economics or psychology.

${ }^{42}$ See: C.F. Camerer, G. Loewenstein, Behavioral economics: Past, present, future [in:] Advances in behavioral economics, ed. C.F. Camerer, G. Loewenstein, Princeton University Press, Princeton 2004, pp. 3-53.

${ }^{43}$ D. Kahneman, A. Tversky, Prospect theory: An analysis of decision under risk, "Econometrica: Journal of the Econometric Society" 1979, Vol. 47, No. 2, pp. 263-291; D. Kahneman, Thinking, fast and slow, Macmillan, 2011.

${ }^{44}$ M.A. Ferber, J.A. Nelson, Beyond economic man: feminist theory and economics, The University of Chicago Press, Chicago 1993; J. Nelson, Feminist Economics at the Millennium: A Personal Perspective, "Signs: Journal of Women in Culture and Society" 2000, Vol. 25, No. 3, pp. 1177-1181; G. Hewitson, Feminist economics as a Postmodern Moment, "Review of Social Economy" 2007, Vol. 65, No. 2, pp. 187-193.

${ }^{45}$ Represented by Herbert Marcuse, Theodor Adorno.
} 
between men and women as resulting in different values and ways of behaving, and maintains that both are equally important. At the social level, feminist economics refers to social justice, by discussing the problem of the power-related hierarchy of values, which understates the values represented by women, minorities and the disabled. The relationship to nature plays an important role at the individual and social level of the human being. To a great extent in feminist economics, ecological problems are of importance. ${ }^{46}$ Solving ecological problems requires people to take care of society and have some moral standards, and economics has to reflect this. ${ }^{47}$ The assumption of a culturally differentiated concept of the human results in a descriptive and normative attitude to researching problems. Feminist economists 'dig into the particulars of the situation and join in dialog with a proper attitude of modesty, rather than pretend to preach from an imaginary value-free and perfectly rigorous platform located somewhere outside our ecological world and our diverse society. ${ }^{48}$ The basic question is: 'How do we want to live, in the light of the effects of our life choices on other people and living beings, now and in the future?' It can be considered an ethical question, as long as it assumes the existence of some common interests of humanity.

Evolutionary economics ${ }^{49}$ assumes that the human being is a satisfier and not an optimizer. His behavior is motivated by 'adjusting to the environment', which includes both egoistic and altruistic behavior. This includes processes of learning, which are combined with obtaining and passing knowledge to/from others by means of education, production, work and, most of all, within firms. The person is perceived as a holon, he is heterogeneous, interdependent, embedded in the social and natural world, motivated by various needs - altruistic and egoistic - and is cooperative and competitive. This translates into the interest of evolutionary economics in analyzing economic problems in a more ethical way, speaking not of economic growth but of development, dealing with human behavior beyond the market, treating the market as an open and autopoietic system (depending on a real human person respecting their values), institutional and economic change and, most of all, by exploring the problem of knowledge as a central force in the development of the economy, also including ethical aspects. ${ }^{50}$

Ecological economics ${ }^{51}$ looks to solve problems by acknowledging the dependence of economic systems on social end ecological ones. This situates the human, with his needs and wants, in a broader context. The social embedding of the human being

\footnotetext{
${ }^{46}$ Feminist economists concerned about ecological problematic build part of the feminist economic school, which is referred as feminist ecological economics.

${ }^{47}$ J.A. Nelson, op. cit., pp. 441-447.

${ }^{48}$ Ibidem.

${ }^{49}$ K.E. Boulding, What is evolutionary economics?, "Journal of Evolutionary Economics" 1991, Vol. 1, No. 1, pp. 9-17; Idem, Evolutionary Economics, Sage, London 1981; K. Dopfer, J. Potts, On the Theory of Economic Evolution, "Evolutionary and Institutional Economics Review" 2009, Vol. 6, No. 1, pp. 23-44; D.B. Hamilton, Evolutionary economics: A study of change in economic thought, Transaction Publ., New Brunswick, NJ 1991.

${ }^{50}$ A. Horodecka, The goal and field of evolutionary and neoclassical economics as a consequence of the changes in concepts of human nature, 15th EBES Conference, Lisbon, Portugal, January 8-10, 2015.

${ }^{51}$ H.E. Daly, J. Farley, Ecological Economics: Principles and Applications, Island Press, Washington, DC 2010; C. Becker, The human actor in ecological economics: Philosophical approach and research perspectives, "Ecological economics" 2006, Vol. 60, No. 1, pp. 17-23; M. Faber, R. Manstetten, J. Proops, Ecological Economics. Concepts and Methods, Edward Elgar, Cheltenham 1996.
} 
makes it necessary for him to respect some social values, and nature, even in the case when they do not match private interests. This brings us to some transindiviudal norms and values which humanity has to respect, like intergenerational justice and respect for other lifestyles. ${ }^{52}$

The humanistic economic ${ }^{53}$ approach is, per definition, an ethical one, because it is based on the assumption that the person is pursuing his self-development, which refers not only to inner qualities like character and virtues, but it considers norms and values as immanent to all deeds of a person and society. It also assumes that only reasoning should take the central role in solving problems. The analysis of economic problems refers to some objective norms and rules, for instance justice and human dignity, which are protected by human rights. The same concerns the attitude of economic thought as developed within some world religions (like Buddhism, Islam and Christian-Catholic teaching). These 'religious' schools of economics can be considered as a part of humanistic economics, which perceives human actions in the light of some transindividual values. World religions pay much attention to the problems of ecological devastation, which is a consequence of the assumption that the world belongs to God and was left to humans only for custody, ${ }^{54}$ or is, in fact, God himself. ${ }^{55}$ The assumption by humanist economics and religious motivated economic schools that a person aims to reach highest level of self-realization - transcendence - means eventually being free of self-focus, self-relating, self-interest and orientation on some general principles, interests and needs. This opens up many possibilities for ethical discourse.

\section{Conclusion}

The changes in the way we speak and think about human nature contribute to the growing criticisms about contemporary problems in the economy and economics, and interests in economic ethics. The consequence of this interest translates into the emergence of various economic ethical schools which focus on those mentioned problems and look for their solution. The chance of solving those problems is perceived in letting in ethical reasoning into economics by, for instance, taking greater control and, at the local, state and global level of economics, developing social capital, strengthening the diverse social institutions, especially those which enforce the moral behaviour in society.

Table 1 delivers an overview of the discussed modern heterodox economic schools regarding their attitude to human nature at the individual and supra-individual level (social and global). Concluding, we can say that the human being is viewed in

\footnotetext{
${ }^{52}$ Ecological economics includes in its analysis the intrinsic value of nature.

${ }^{53}$ M.A.X. Lutz, Economics for the Common Good: Two Centuries of Economic Thought in the Humanist Tradition, Routledge, 2002; B.C. Beaudreau, A humanistic theory of economic behavior, "The Journal of Socio-Economics" 2012, Vol. 41, No. 2, pp. 222-234; M.A. Lutz, K. Lux, Humanistic economics: the new challenge, Bootstrap Press, New York, NY 1988.

${ }^{54}$ Transcendental religions: Judaist, Christian and Islam tradition, see: A. Horodecka, Światowe religie wobec współczesnych wyzwań rozwojowych [The response of world religions to today's development challenges], [in:] J. Stacewicz, Szkoła Główna Handlowa w Warszawie, Warsaw 2015.

55 The immanent nature of God - characteristic, for instance, of Hinduism.
} 
more dimensions, including social and global ones. For the individual level, the human being is perceived more and more as dependent on society, a particular time culture, and is motivated by both egoistic and altruistic reasons. They make cooperation possible, which lies in the foundations for looking for common norms and values, discussed at the social level (respecting its plurality) and impacting the relationship to nature (growing relevance).

Table 1. Ethical aspects of contemporary economic heterodox thought

\begin{tabular}{|c|c|c|}
\hline & Individual world & Social world and worldview \\
\hline Behavioral & $\begin{array}{l}\text { The emotional and rational nature of } \\
\text { human beings (bounded rationality) } \\
\text { External (framing) and internal (per- } \\
\text { sonality, aversion to risk) factors shape } \\
\text { human behavior }\end{array}$ & $\begin{array}{l}\text { The relationship between people based } \\
\text { on reciprocity not on maximizing util- } \\
\text { ity, therefore ethical behaviors are pre- } \\
\text { ferred as long as someone does not } \\
\text { harm them (tit for tat) }\end{array}$ \\
\hline Feminist & $\begin{array}{l}\text { Pluralistic view on human nature - } \\
\text { feminine and masculine, necessity of } \\
\text { integration of their values: rational- } \\
\text { emotional, autonomous-dependent, } \\
\text { egoistic-altruistic, rational choice - in- } \\
\text { tuitive, preferences - needs }\end{array}$ & $\begin{array}{l}\text { Social / cultural embedding of the in- } \\
\text { dividual } \\
\text { The superiority of only masculine val- } \\
\text { ues contradicts the equality, plurality } \\
\text { and complexity of society } \\
\text { Environmental aspects discussed } \\
\text { widely in the ecological feminist ap- } \\
\text { proach (relationship to nature is com- } \\
\text { bined with the social structure) }\end{array}$ \\
\hline Humanist & $\begin{array}{l}\text { The dual-self concept (self-interest/so- } \\
\text { cial interest, egoistic/altruistic, lower } \\
\text { needs (wants)/higher needs, mate- } \\
\text { rial/non-material, } \quad \text { short/long-life } \\
\text { needs), with the assumption that the } \\
\text { person tends to choose a higher self } \\
\text { (self-realization/transcendence) }\end{array}$ & $\begin{array}{l}\text { The human is in the center of the world, } \\
\text { the world is a reflection of him - econ- } \\
\text { omy and society shall support human } \\
\text { development and allow him to satisfy } \\
\text { his needs } \\
\text { Society and culture evolve } \\
\text { Harmony within society is superior to } \\
\text { economic growth }\end{array}$ \\
\hline Ecological & $\begin{array}{l}\text { Competition (h. oec.) \& cooperation } \\
\text { ( } h \text {. reciprocans \& communicus) are } \\
\text { possible only by acknowledging some } \\
\text { norms; bounded rationality: emotional } \\
\text { and rational; wellbeing has material } \\
\text { and non-material elements (happiness, } \\
\text { the role of internal factors); procedural } \\
\text { utility and not possessive one }\end{array}$ & $\begin{array}{l}\text { The world system is a closed one, } \\
\text { therefore the economic system has to } \\
\text { respect the borders put in place by the } \\
\text { social (social-cultural) and ecological } \\
\text { system } \\
\text { The biophysical foundations of eco- } \\
\text { nomics put economics into some real } \\
\text { frames again }\end{array}$ \\
\hline Evolutionary & $\begin{array}{l}\text { Satisfying and not optimizing behavior, } \\
\text { motivated by adjusting to the environ- } \\
\text { ment and passing knowledge, is both al- } \\
\text { truistic and egoistic }\end{array}$ & $\begin{array}{l}\text { The interest of the group is necessary } \\
\text { for the survival of the individual: the } \\
\text { balance of cooperation and competition } \\
\text { Society influences the individuals in } \\
\text { their choices }\end{array}$ \\
\hline
\end{tabular}

Source: own elaboration.

The following table (Table 2) provides some insight into the changes in understanding the goal and field of particular heterodox economic schools. They reveal the possibilities for the economy to gain an ethical face, as long as they get back to man's real needs and those of his environment, which would allow a discourse about 'good' and 'bad' to take place, as long as we no longer deal with abstract phenomena like the market and efficiency, but deal with real individuals, society 
and problems. This means, as the table demonstrates, the reintegration of political, social and ethical issues into economics. Whereas political issues are based on ethical language - rights, values, norms, social - there is no specific language for such a discourse which is geared toward needs, which are the basis of the development of the human character. Heterodox economics attempts to overcome this difficulty. The goal of economics is now wellbeing, such as accomplishing various and real human needs, both material and non-material ones (rights, values).

Table 2. Changes in the goal and field within heterodox economics - chances for the ethical face of economics

\begin{tabular}{|l|l|l|}
\hline & \multicolumn{1}{|c|}{ Goal } & \multicolumn{1}{|c|}{ Field } \\
\hline $\begin{array}{l}\text { Evolutionary } \\
\text { economics }\end{array}$ & $\begin{array}{l}\text { Discovery of the rules of adapting } \\
\text { to the changing conditions and pro- } \\
\text { cesses of the emergence of the } \\
\text { most effective rules }\end{array}$ & $\begin{array}{l}\text { The knowledge and its transfer with the } \\
\text { help of institutions, technology and prod- } \\
\text { ucts, and the process of learning and selec- } \\
\text { tion }\end{array}$ \\
\hline $\begin{array}{l}\text { Humanist } \\
\text { economics }\end{array}$ & $\begin{array}{l}\text { Covering of human needs, better- } \\
\text { ing of the conditions of economic } \\
\text { activity }\end{array}$ & $\begin{array}{l}\text { Human rights, the sustainability of the econ- } \\
\text { omy, protection of the environment, ethics, } \\
\text { social relations }\end{array}$ \\
\hline $\begin{array}{l}\text { Behavioral } \\
\text { economics }\end{array}$ & $\begin{array}{l}\text { Providing the empirical basis to the } \\
\text { concept of human nature in order } \\
\text { to explain basic processes in eco- } \\
\text { nomics }\end{array}$ & $\begin{array}{l}\text { Decision-making processes } \text { (heuristics, } \\
\text { framing, imperfections) and their conse- } \\
\text { quences for the individual and society }\end{array}$ \\
\hline $\begin{array}{l}\text { Ecological } \\
\text { economics }\end{array}$ & $\begin{array}{l}\text { Improve wellbeing through devel- } \\
\text { opment, institutions and a sustain- } \\
\text { able ecosystem }\end{array}$ & $\begin{array}{l}\text { Interdependence and co-evolution of eco- } \\
\text { nomics and natural ecosystems }\end{array}$ \\
\hline $\begin{array}{l}\text { Feminist } \\
\text { economics }\end{array}$ & $\begin{array}{l}\text { Solving specific mostly practical } \\
\text { problems in the economy through } \\
\text { economics }\end{array}$ & $\begin{array}{l}\text { Decisions in the market and beyond, the val- } \\
\text { ues of gender }\end{array}$ \\
\hline
\end{tabular}

Source: own elaboration.

\section{References}

Apel K.-O., Das Apriori der kommunikationsgemeinschaft, Suhrkamp, 1976.

Apel K.-O., Globalization and the need for universal ethics, "European Journal of Social Theory" 2000, Vol. 3, No. 2, pp. 137-155.

Apel K.-O., Grenzen der Diskursethik? Versuch einer Zwischenbilanz, "Zeitschrift für philosophische Forschung" 1986, pp. 3-31.

Apel K.-O., The situation of humanity as an ethical problem, "Praxis International" 1984, No. 3, pp. 250-265.

Beaudreau B.C., A humanistic theory of economic behavior, "The Journal of Socio-Economics" 2012, Vol. 41, No. 2, pp. 222-234.

Becker C., The human actor in ecological economics: Philosophical approach and research perspectives, "Ecological economics" 2006, Vol. 60, No. 1, pp. 17-23.

Becker G.S., The economic approach to human behavior [in:] The Economics Approach to Human Behavior, ed. G.S. Becker, University of Chicago Press, Chicago 1976, pp. 3-14.

Bentham J., J.S. Mill, The utilitarians, Anchor Press, Garden City, NY 1973. 
Boulding K., Evolutionary Economics, Sage, London 1981.

Boulding K.E., What is evolutionary economics?, "Journal of Evolutionary Economics" 1991, Vol. 1, No. 1, pp. 9-17.

Bowie N.E., A Kantian Theory of Meaningful Work, "Journal of Business Ethics" 1998, Vol. 17, pp. 1083-1092.

Camerer C.F., G. Loewenstein, Behavioral economics: Past, present, future [in:] Advances in behavioral economics, ed. C.F. Camerer, G. Loewenstein, Princeton University Press, Princeton 2004, pp. 3-53.

Charuseela S., Social Analysis and the Capabilities Approach: A Limit to Martha Nussbaum's Universalist Ethics, "Cambridge Journal of Economics" 2009, Vol. 33, No. 6, pp. 1135-1152.

Collins D., Essentials of business ethics: Creating an organization of high integrity and superior performance, John Wiley \& Sons, 2009.

Daly H.E., J. Farley, Ecological Economics: Principles and Applications, Island Press, Washington, DC 2010.

Dopfer K., J. Potts, On the Theory of Economic Evolution, "Evolutionary and Institutional Economics Review" 2009, Vol. 6, No. 1, pp. 23-44.

Dzionek-Kozłowska J., Ekonomia jako nauka pozytywna. Refleksje na marginesie „Ekonomii dobra i zła" Tomáša Sedláčka, "Annales. Etyka w Życiu Gospodarczym", Vol. 16, pp. 335-344.

Dzionek-Kozlowska J., R. Matera, Ethics in Economic Thought. Selected Issues and Various Perspectives, Lodz University Press, Jagiellonian University Press, Lodz-Cracow 2015, pp. 81-89.

Eisenhardt K., Agency theory: An assessment and review, "Academy of Management Review" 1989, Vol. 14, No. 1, pp. 57-74.

Etzioni A., The Essential Communitarian Reader, Rowman \& Littlefield, Lanham 1998.

Etzioni A., Toward a Kantian Socio-Economics, "Review of Social Economy” 1987, Vol. 45, No. 1.

Etzioni A.X., Moral Dimension: Toward a New Economics, Simon and Schuster, 2010.

Faber M., R. Manstetten, J. Proops, Ecological Economics. Concepts and Methods, Edward Elgar, Cheltenham 1996.

Ferber M.A., J.A. Nelson, Beyond economic man: feminist theory and economics, The University of Chicago Press, Chicago 1993.

Habermas J., Moralbewusstsein und kommunikatives Handeln, Suhrkamp, Frankfurt am Main 2001.

Habermas J., Philosophische Anthropologie, [in:] Kultur und Kritik, ed. J. Habermas, Suhrkamp, Frankfurt 1973.

Habermas J., The Theory of Communicative Action: Reason and the rationalization of society, Beacon Press, 1987.

Hamilton D.B., Evolutionary economics: A study of change in economic thought, Transaction Publ., New Brunswick, NJ 1991.

Herman A., Dokąd zmierza ekonomia?, "Kwartalnik Nauk o Przedsiębiorstwie” 2008, No. 2, pp. 4-13. 
Hewitson G., Feminist economics as a Postmodern Moment, "Review of Social Economy" 2007, Vol. 65, No. 2, pp. 187-193.

Hodgson G.M., From Pleasure Machines to Moral Communities, An Evolutionary Economics without Homo economicus, University of Chicago Press, Chicago 2012.

Höffe O., Humanität [in:] Lexikon der Ethik, ed. O. Höffe, München 1980, pp. 112-113.

Homann K., F. Blome-Drees, Wirtschafts- und Unternehmensethik, Vandenhoeck \& Ruprecht, Göttingen 1992.

Horodecka A., E. Mazur-Wierzbicka, The meaning of the concept of human nature in the organization and ethical concepts supporting CSR, [in:] CSR - Społeczny wymiar działalności biznesowej, ed. E. Mazur-Wierzbicka, Economicus, Szczecin 2014.

Horodecka A., Homo oeconomicus, jako podstawa ekonomii - krytyka i alternatywy [Homo economicus, as the basis of economics - criticism and alternatives], "Prace Naukowe Uniwersytetu Ekonomicznego we Wrocławiu” 2014, No. 347, pp. 166-183.

Horodecka A., Komponenty obrazu czlowieka w ekonomii [Components of the concept of human nature in economics]. "Kwartalnik Historii Myśli Ekonomicznej [Quarterly History of Economic Thought]" 2014, Vol. 5, No. 1, pp. 117-139.

Horodecka A., Rola obrazów człowieka w koncepcjach zarządzania z uwzględnieniem aspektów metodologicznych [The role of human images in the concepts of management, taking into account methodological aspects], [in:] Studia Ekonomiczne Nauki o zarządzaniu - u początków i wspótcześnie, ed. A. Czech, Uniwersytet Ekonomiczny w Katowicach, Katowice 2012, pp. 443-464.

Horodecka A., Światowe religie wobec wspótczesnych wyzwań rozwojowych [The response of world religions to today's development challenges], [in:] J. Stacewicz, Szkoła Główna Handlowa w Warszawie, Warsaw 2015.

Horodecka A., The goal and field of evolutionary and neoclassical economics as a consequence of the changes in concepts of human nature, $15^{\text {th }}$ EBES Conference, Lisbon, Portugal, January 8-10, 2015.

Horodecka A., The Meaning of Concepts of Human Nature in Organizational Life in Business Ethical Context, "Annales. Etyka w Życiu Gospodarczym / Annales. Ethics in Economic Life" 2014, Vol. 17, No. 4, pp. 53-64.

Kahneman D., A. Tversky, Prospect theory: An analysis of decision under risk, "Econometrica: Journal of the Econometric Society" 1979, Vol. 47, No. 2, pp. 263-291.

Kahneman D., Thinking, fast and slow, Macmillan, 2011.

Karmasin M., M. Litschka, Wirtschaftsethik: Theorien, Strategien, Trends, Lit-Verl., Wien 2008.

Klimczak B., Model człowieka gospodarującego we współczesnej ekonomii [in:] Wizerunek wspótczesnego człowieka gospodarującego, ed. A. Węgrzycki, Akademia Ekonomiczna w Krakowie, Cracow 2000, pp. 11-29.

Kołodko G.W., Dokąd zmierza świat. Ekonomia polityczna przyszłości, Prószyński i S-ka, Warsaw 2013.

Kołodko G.W., Wędrujący świat, Prószyński i S-ka, Warsaw 2008.

Lin N., Social Capital: A Theory of Social Structure and Action (Structural Analysis in the Social Sciences), Cambridge University Press, Cambridge 2002.

Lutz M.A., K. Lux, Humanistic economics: the new challenge, Bootstrap Press, New York, NY 1988. 
Lutz M.A.X., Economics for the Common Good: Two Centuries of Economic Thought in the Humanist Tradition, Routledge, 2002.

Nelson J., Feminist Economics at the Millennium: A Personal Perspective, "Signs: Journal of Women in Culture and Society" 2000, Vol. 25, No. 3, pp. 1177-1181.

Nelson J.A., Economists, value judgments, and climate change: A view from feminist economics, "Ecological economics" 2008, Vol. 65, No. 3, pp. 441-447.

Nussbaum M.C., Capabilities as fundamental entitlements: Sen and Social Justice, "Feminist Economics" 2003, Vol. 9, No. 2, pp. 33-59.

Pelenc J., M.K. Lompo, J. Ballet, J.-L. Dubois, Sustainable human development and the capability approach: Integrating environment, responsibility and collective agency, "Journal of Human Development and Capabilities" 2013, Vol. 14, No. 1, pp. 77-94.

Pieper A., Einführung in die Ethik [in:] Mut zum Aufbruch. Eine wirtschaftspolitische Agenda für die Schweiz, ed. D. Hauser, H.B. Schmid, Zürich 1995.

Rich A., Wirtschaftsethik: Grundlagen in theologischer Perspektive, Gütersloher Verlagshaus, Gütersloh 1984.

Sedláček T., Ekonomia dobra i zła, Wydawnictwo EMKA, Warsaw 2012.

Sen A.K., Commodities and Capabilities, North-Holland, Amsterdam 1985.

Sen A.K., Development as freedom, Univ. Press, Oxford 2001.

Sen A.K., Inequality Reexamined, Russell Sage, New York 1992.

Stacewicz J., Etyczne przesłanki działania gospodarczego, "Problemy” 1988, No. 4, pp. 1-5.

Ulrich P., Integrative Economic Ethics: Foundations of a Civilized Market Economy, Cambridge University Press, Cambridge 2008.

Ulrich P., Integrative Wirtschaftsethik: Grundlagen einer lebensdienlichen Ökonomie, Haupt, Bern 2001.

Ulrich P., Integrative Wirtschaftsethik: Grundlagenreflexion der ökonomischen Vernunft, "Ethik und Sozialwissenschaften" 2000, Vol. 11, No. 4, pp. 555-567.

Ulrich P., Integrative Wirtschaftsethik—eine Heuristik auch für die Technikethik? [in:] Technikethik und Wirtschaftsethik, Springer, 1998, pp. 53-74.

Wieland J., Corporate governance, values management, and standards: an European perspective, "Business \& Society" 2005, Vol. 44, No. 1, pp. 74-93.

Wieland J., Die Ethik der Governance, Metropolis-Verl., Marburg 2004.

Wieland J., Eine Theorie der Governanceethik, "Zeitschrift für Wirtschafts-und Unternehmensethik" 2001, Vol. 2, No. 1, pp. 8-33.

Wieland J., Governance ethics: Global value creation, economic organization and normatively, Springer, 2014.

http://go.worldbank.org/K4LUMW43B0.

http://go.worldbank.org/XR8TFW7L20 